Iryna Saukh,

Dr.Sc., Professor, Zhytomyr State University named after Ivan Franko, Ukraine

(D) ORCID ID, 0000-0002-3812-6579

email: irina_saukh@ukr.net

Olha Vikarchuk,

Ph.D., Associate Professor, Zhytomyr State University named after Ivan Franko, Ukraine

(D) ORCID ID, 0000-0001-7574-5347

email: viktoriya98@ukr.net

Correspondence author: irina_saukh@ukr.net

\title{
CREATIVITY IN MANAGEMENT AND CREATIVE MANAGEMENT: META-ANALYSIS
}

Abstract. In the article the authors stated that management had become one of the major factors in the efficiency and competitiveness of developed countries' economies during the twentieth century. The tendency of scales steady growth and a share of organizational-managerial innovations in the total volume of organization management activity is proved. The essence of the "creative management» concept is revealed as a component of the enterprise management system. The paper aims to analyze the approaches to define the main research directions in creative management and creativity in management. The analysis findings proved that creative management or creativity in management issues is one of the mainstream of investigation in papers devoted to modern management, which formed different scientific directions. The findings of investigation allow concluding that the topic of "creative management» or "creativity in management» wasn't popular among scientists until 2004 according to the WoS database and 2006 according to Scopus. After these years, the numbers of papers were growing up to 2018 throughout the analyzed period at an average growth rate of almost 50\% in WoS database and $39 \%$ in Scopus database. Using VOSviewer software allowed defining 8 clusters of keywords that analyzed the creative management or creativity in management issues. All of them have close connections. The biggest cluster consists of 60 items and includes the follows big data, commerce, communication, competition, competitiveness, creative management, creative society, information and communication, information society, information management, information system, information technology, knowledge-based system, knowledge management, SMEs, surveys, strategic planning, sustainable development, technological development etc. The second biggest cluster merged the sphere of urban economy and the development of the creative industry. The findings proved that intellectual property rights protection is an important part of creative management or creativity in management issues. Creative management or creativity in management issues is becoming popular in the last decade in analyses.

Keywords: creative management, creativity in management, creative economy.

Introduction. According to UNCTAD, modern development is closely linked with the development of creative industries, one of the world's most dynamic sectors. Since 2004, UNCTAD has promoted a global understanding of the creative economy to promote development through creativity, thus bringing the "creative economy» problems to the world economy and development agenda. Areas such as advertising, architecture, arts and crafts, design, fashion, film, video, photography, music, performing arts, publishing, research and development, software, computer games, e-publishing, television and radio are key creative economy industry according to the data. That is confirmed by data from Google trends (Figure 1).

The XXI century era is the era of information and intellectual explosion, the transition from rationality to creativity. R. Florida (Florida, 2011) noted that creativity is a large-scale and continuous practice that

Cite as: Saukh, I., \& Vikarchuk, O. (2021). Creativity in Management and Creative Management: Meta-Analysis. Marketing and Management of Innovations, 1, 65-80. http://doi.org/10.21272/mmi.2021.1-06 
constantly modifies and improves all possible products, processes, and operations in the modern economy.

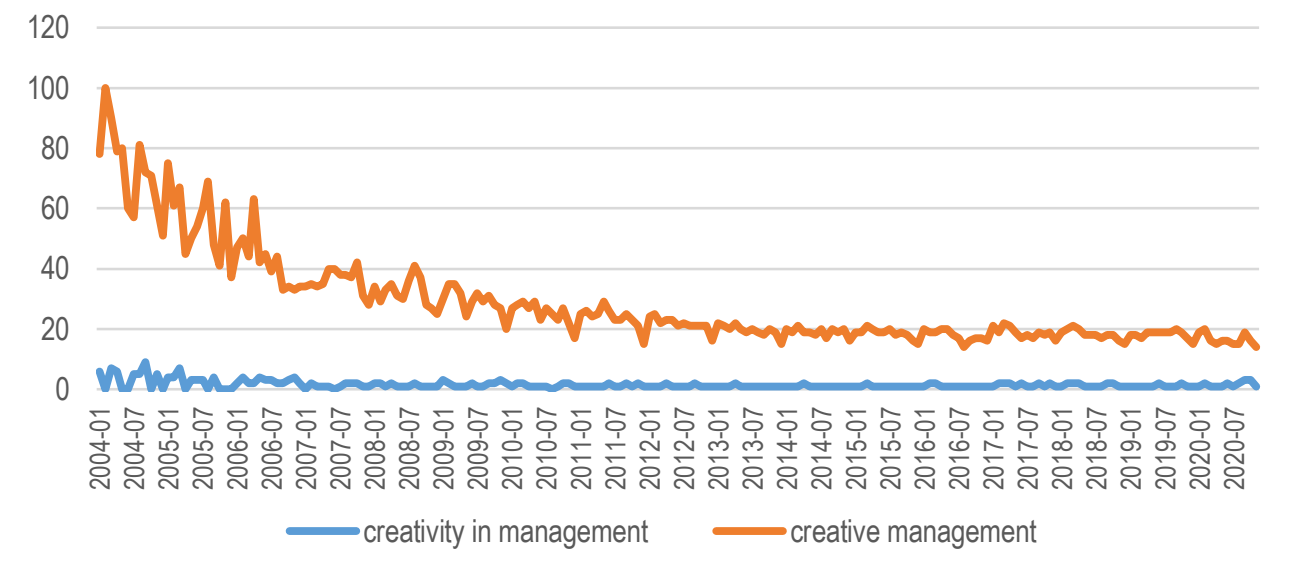

Figure 1. Search interest in terms «creativity in management» and «creative management», month changes, 2004-2020

Sources: developed by the authors using data from Google trends.

According to analysts at the World Economic Forum (WEF, 2020), the ideal employee in 2020 should have at least 10 key competencies. Among them, creativity ranks as third (first and second, respectively - «the ability to solve complex problems» and «critical thinking»). However, almost each of the list's competencies could either be included in the structure of creativity or rely on it. That is especially true of competencies such as «emotional intelligence», «cognitive flexibility», «people management», which indicates the demand for creativity in the post-industrial economy.

This study provides a review of the scientific background on the relationship between creative management or creativity in management terminology. The main goal is to analyze scientific publications in the field of creative management or creativity in management to answer what other terminology is closely related to the development of the creative economy. It stands to note that traditionally creative management is closely linked with the development of primarily creative industries. The research was limited to a selection of articles published in Scopus or Web of Sciences databases.

Literature review. The use of the terminology of «creative management» in academic and scientific papers is connected recently with developing creativity in solving product creation problems, creative decisions in marketing, etc.

The oldest paper connected with creative management in the Scopus database is (Bordinat, 1961). The author, a Ford Motor Company styling executive Gene Bordinat, believed that most creative product planning comes from the design centre. Thus, the designer makes managers and accouters work with new approaches. According to WoS, the oldest publication (Bliss, 1970) was dedicated to discussing management in public welfare and political and economic restraints on a social service department manager that impedes creative management techniques.

A considerable amount of publications were devoted to the education and training of managers to improve their creativity. The first article in this sphere indexed by the Scopus and WoS databases is (Burstiner, 1977). This study reports the effects of a workshop fostering creative problem-solving approaches based on the experimental group improved on supervisors' creativity ratings and several 
subscores of the Torrance Tests of Creative Thinking, Verbal Forms, and the Creativity/Leadership SelfRating Chart. The current article (Yakymchuk et al., 2020) showed that using an applied «semi-virtual» learning environment aimed at the "creative economy» model combined with regular brain and memory training is capable of fostering cognitive and creative thinking styles when integrated into the process of vocational education and training of the students majoring in Art and Design.

A huge area of investigation belongs to the developing of the creative economy. The oldest article in this area indexed by Scopus (Beswick, 1988) argued that a radically different orientation in higher education development in Australia is required. First of all, the way of recovery of at least shared responsibility by the states and the development of private initiatives should promote more creative management by diversifying funding sources and lines of accountability. Then, it would make personal and national economic changes. It is worth mentioning the recent study (Yue and Zhao, 2020). The authors tried to evaluate higher education institutions' effectiveness to bring up human resources, made some conclusions, and provided evidence of the important role of higher education in the creative economy. The authors noted that the effect of higher education policies differed between countries. The oldest article in the WoS database (Zelina, 1992) showed the analysis of trends in creativity. The author proved that the school and education system forms the creative management system based on children's education within the family.

Many papers were dedicated to creative management in the health sphere and creative way in hospital management. One of the first articles in this area (Pointer, 1976) investigated management and unions' relation in Catholic hospitals. Thus, the obtained results proved the thesis that competent and creative management could be a better way to governance in the feature of destitution of a union. In turn, it is necessary to mention the recent paper (Rosiek-Kryszewska and Rosiek, 2018) presented the debate on leadership features and their impact on creating an innovative culture of the firm and building a competitive advantage in the health care industry. According to WoS, the first paper (Bennett, 1979) discussed the demand of hospitals in creative management engineers to make innovative changes, build corporate climate and training systems, and their relations with hospital administrators. One of the recent articles (Sengun, 2016) was dedicated to conceptual changes in the healthcare sphere based on innovative practices, place, and importance for developing Turkey's healthcare system. The study (Zhou et al., 2020) focused on organizing the medicines' transportation logistics based on resource semantic discovery process and cloud medical service scenario.

Many papers indexed by Scopus and WoS databases were dedicated to the development of creative cities. Thus, one of the earliest articles in this sphere indexed by both databases is (Donegan and Lowe, 2008). The authors investigated the complicated connections between creative employees and emoluments inequality in the urban economy context. They proposed some labour market institutions and legislative supports to solve this problem. Among the last articles indexed by Scopus is (Esen and Atay, 2020). This article aimed to check the relationship between creativity levels (calculated by using technology, tolerance, talent variables and the indexing method of Global Creativity Index) and the development of Turkey's cities. According to WoS, one of the recent papers in this area (Teresa and Zitcer, 2020) was devoted to evaluating perspectives of the role of artists as drivers of economic growth and urban vitality in Philadelphia, Pennsylvania.

Since 2000 the papers were devoted to connections of creativity and development of small and medium enterprises and entrepreneurship (SME). Among the oldest ones, (Banks et al., 2002) focused on new media SMEs in the North West of England. The authors concluded that the influence of creativity was changeable and disputed. In turn, management of creativity is predestinated by the corporate culture, external social and economic features. One of the latest paper (Farida et al., 2021) proved that the marketing performance of SME in the Islamic fashion business in Central Java could be enhanced by improving entrepreneurial orientation and product innovation success. On another side competitor and 
customer sensing capabilities are the bad instruments to improve marketing performance. Among recent article indexed in WoS is (Rosyadi et al., 2020). This study aimed to enunciate a consolidated mentoring model based on multi-stakeholder cooperation for small and medium enterprises in the creative sector of the economy of Banyumas Regency, Central Java, Indonesia. That should comprise next aspects: marketing development, business permit and legal business entity, social media and information technology, financial management and intellectual property protection, internationalization of market and entrepreneurship development.

It stands to mention the significant number of publications dedicated to the protection of intellectual property right as part of creative management. The oldest paper indexed in Scopus (Edwards et al., 2013) described the fails of regulation to control user behaviour with illegal downloading. The authors proposed some way of the copyright policymaking process based on modes of justification offered by users. In the most recent paper (Nurani et al., 2020), the authors proved the inadequate protection of intellectual property right in Indonesia's culinary industry. They noted that it stimulated plagiarism and imitation as a form of picaresque business competition and hampered the creative economy's growth. The authors tried to rethink the role of law in solving the important governance problems in the creative economy, connected to cultural and trade inclusion, considering transforming economic offerings in the cultural industries backed by modern technological innovations. The oldest article in the WoS database is (Neuwirth, 2013). It was aimed at rethinking the role of law in solving the important governance problems in the creative economy, connected to cultural and trade inclusion, taking to account transforming the nature of economic proposals in the cultural industries backed by modern technological innovations. One of the recent papers is (Rodríguez Gomez and Rojas Rosario, 2018). The authors examined the system of the legal protection of products of "orange economy» (variation of the creative economy in Colombia), the Apps or mobile applications, from the point of view of the Colombian legal system and the supranational Andean regulations that protect such innovations and the products and services connected to them.

The systematization of scientific background showed a wide range of investigations of the creative management or creativity in management and various aspects of this scientific area's coverage. However, the general impact of creative management and creative economy on regional development and national economy and the creative management direction in the digital age have not been studied sufficiently. Based on the above, the article aims to analyze the vectors in the scientific literature on creative management or creativity in management to identify future prospective research areas.

Methodology and research methods. This study is based on the meta-analyses' approach proposed in the paper (Boiarko, 2016; Kuznyetsova et al., 2018; Rausser et al., 2018; Kuzior et al., 2019; Tkachenko et al., 2019; Kuznyetsova et al., 2019; Vasylieva et al., 2020). This approach involves cope goal to define trends in investigations of the creative management or creativity in management issues and based on the following algorithm:

1. Evaluating the volume tendency of the investigations dedicated to creative management or creativity in management issues.

2. Collocating the main subject sphere of researches in creative management or creativity in management issues.

3. Defying the most citation papers and Journals associated with «creative management» or «creativity in management».

4. Clustering the research on the main vectors for investigations to define the possible directions for surveys in areas of creative management or creativity in management.

The following keywords were used for the analysis: creative management, creativity in management, management and creative economy/creative economic. This research is based on the papers indexed by Scopus (1202) and Web of Science (975) databases. The publication period for documents indexed by the Scopus database is from 1950 to present, for documents indexed by WoS database - from 1970 to 
present. VOSviewer software tools were used to define and visualize the network of keywords used in the co-cited paper dedicated to creative management or creativity in management issues. Scopus and WoS analyses tools provided the publications' clustering according to authors affiliations, source of publications, number of citations, the subject areas etc.

Results. The findings of investigation allow concluding that, in the WoS database, the topic of «creative management» or «creativity in management» hadn't been popular among scientists until 2004, while in the Scopus - until 2006. Then the numbers of papers had been growing up to 2018 throughout the analyzed period. The average growth rate was approximately $50 \%$ in the WoS database and $39 \%$ in the Scopus database. It could be explained by the active spread of problems associated with the active introduction of digital technologies in all spheres of public life and economy, which required the search for new creative solutions in management, regulation etc. In 2018, the number of works in the WoS database, which analyzed the issues of creative management and creativity in management, increased 645 times compared to 2005. A similar figure in Scopus compared to 2003 increased by $4300 \%$ (Figure 2).

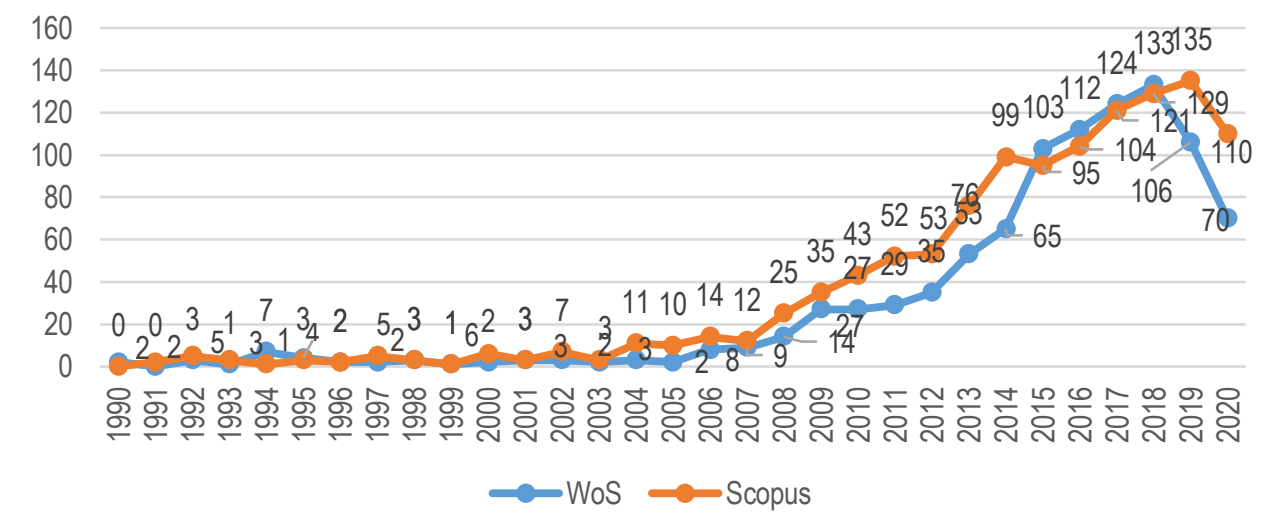

Figure 2. The number of documents in Scopus and WoS which contain the creative management or creativity in management

Sources: developed by the authors using data from Scopus and WoS.

The results of using Scopus analyses tools proved that the creative management or creativity in management was investigated in subject areas such as Social Sciences - 33.95\%; Business, Management and Accounting - 14.25\%; Arts and Humanities - 10.41; Economics, Econometrics and Finance-9.44\%; Environmental Science - 6.08\%; Engineering - 5.74\%; Computer Science - 5.3\%; Earth and Planetary Sciences - 3.6\%; Decision Sciences - 2.68\% and others (Medicine, Psychology, Energy, Agricultural and Biological Sciences, Materials science etc. - 16 subject areas with share $<1 \%)-8.56 \%$.

The results of using Wos analyses tools allows defining the following research areas of the creative management or creativity in management issues: Business Economics - 20.26\%; Public administration 7.15\%; Geography - 6.89\%; Social science other topics - 6.62\%; Environmental science ecology and Urban studies $-5.76 \%$ each of them; Cultural studies $-4.97 \%$ and other (65 research areas with share les than $1 \%$ including Education, Educational Research, Arts, Humanities other topics, Communication, Sociology etc.) $-42.58 \%$. 


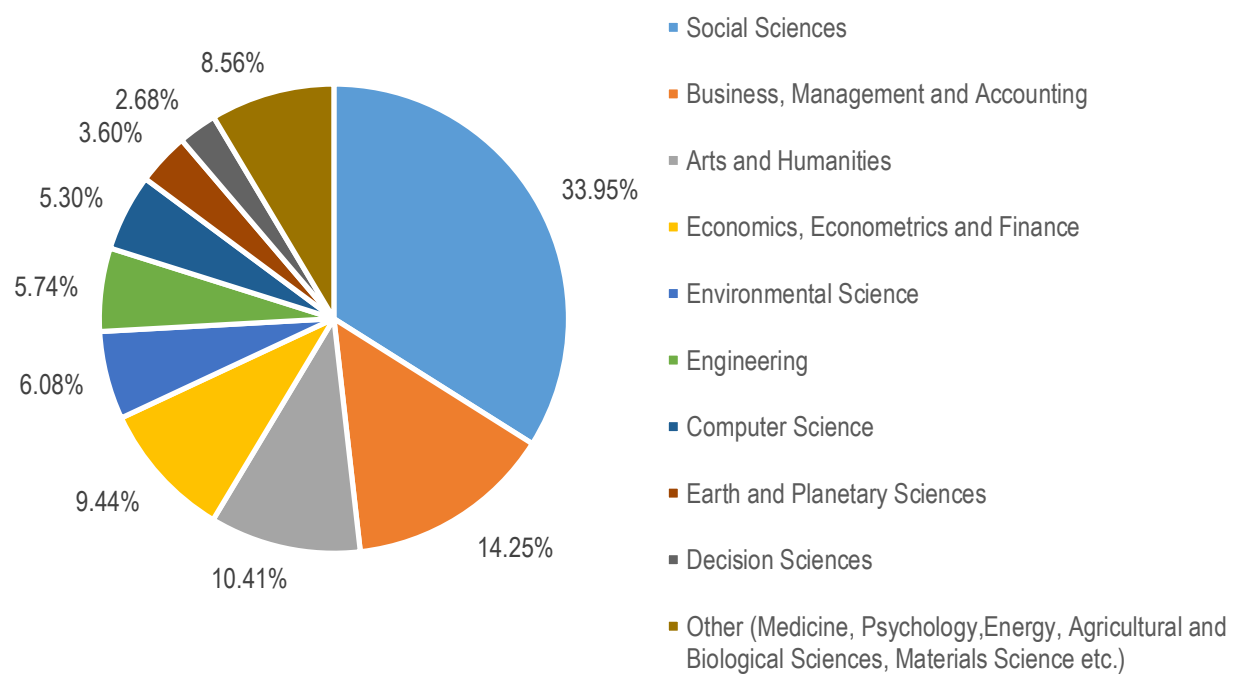

Figure 3. Analyzing the creative management or creativity in management issues by the Scopus subject areas

Sources: developed by the authors using data from Scopus.

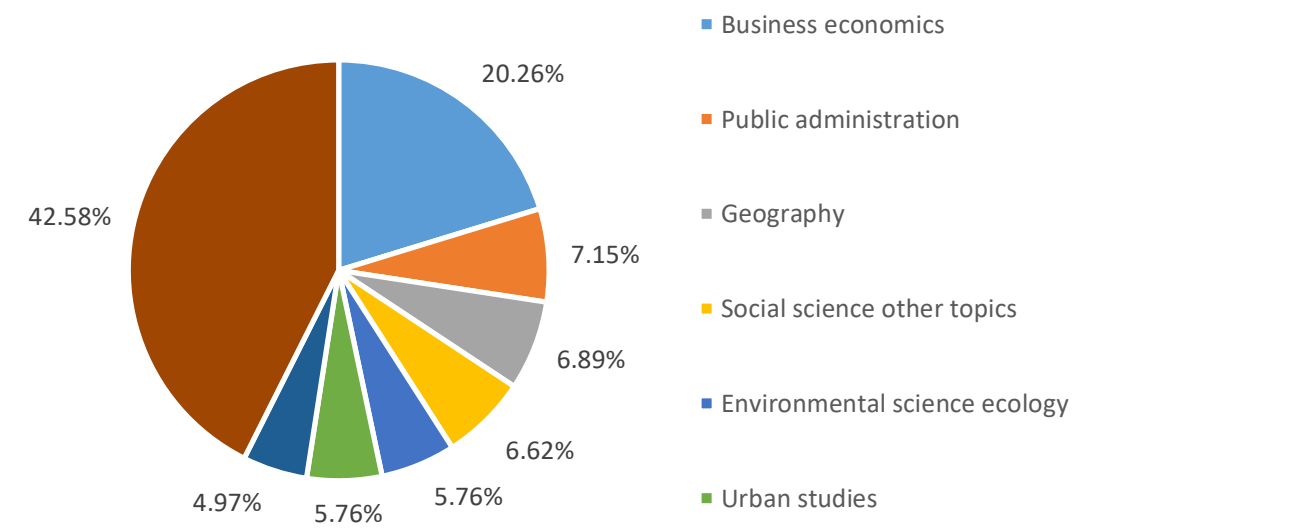

Figure 4. Analyzing the creative management or creativity in management issues the WoS subject areas

Sources: developed by the authors using data from WoS.

Moreover, Scopus and Wos analyses tools allowed identifying the country affiliation of authors of publications in the creative management or creativity in management issues. These analyses demonstrate that the largest number of affiliations in the creative management or creativity in management issues are associated with the following countries: 1) in the Scopus database - the USA, the United Kingdom, Australia and Indonesia; 2) in the WoS database - the USA, the United Kingdom, Brazil and China. Figure 5 presents the number of papers on creative management or creativity in management issues by the top 20 countries' affiliation. 


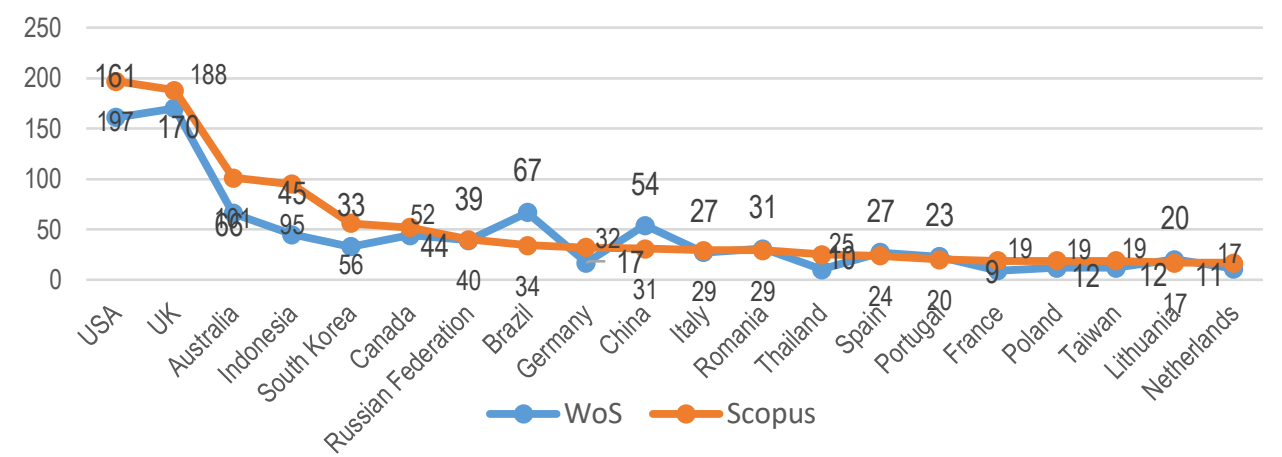

Figure 5. Top-20 country's affiliation of the scientists which investigated the creative management or creativity in management

Sources: developed by the authors using data from WoS and Scopus.

Given the data from WoS and Scopus analyses tools, in 2020 the high ranked (Quartile in Category Q1) journals published most articles on creative management or creativity in management issues were: International Journal of Cultural Policy, Sustainability, Journal of Urban Affairs. It stands to mention that the biggest number of paper was published in high-rank journals (4 out of 5 of the most active journals presented the researches on creative management or creativity in management) (Table 1).

Table 1. The top-5 journals indexed by Scopus and WoS

\begin{tabular}{|c|c|c|c|c|c|c|c|c|c|}
\hline \multirow{2}{*}{$\begin{array}{l}\text { Title of the } \\
\text { Journal }\end{array}$} & \multirow{2}{*}{$\begin{array}{l}\text { Covered by } \\
\text { Scopus }\end{array}$} & \multirow{2}{*}{$\begin{array}{l}\text { Subject } \\
\text { area }\end{array}$} & \multirow{2}{*}{$\begin{array}{l}\underset{0}{\frac{d}{0}} \\
\text { I }\end{array}$} & \multirow{2}{*}{ 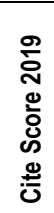 } & \multirow{2}{*}{ 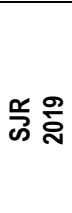 } & \multirow{2}{*}{$\begin{array}{l}\stackrel{0}{2} \\
\text { 号 }\end{array}$} & \multirow{2}{*}{ 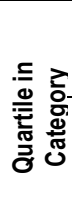 } & \multicolumn{2}{|c|}{$\begin{array}{c}\text { Numbers } \\
\text { of the } \\
\text { papers }\end{array}$} \\
\hline & & & & & & & & 흘 & $\stackrel{\mathscr{0}}{3}$ \\
\hline $\begin{array}{l}\text { International } \\
\text { Journal Of } \\
\text { Cultural Policy }\end{array}$ & $\begin{array}{l}\text { from } 1997 \text { to } \\
\text { Present }\end{array}$ & $\begin{array}{l}\text { Social Sciences: Cultural } \\
\text { Studies; Sociology and } \\
\text { Political Science }\end{array}$ & 42 & 2.4 & 0.607 & 2.162 & Q1 & 29 & 26 \\
\hline Cultural Trends & $\begin{array}{l}\text { from } 1989 \text { to } \\
\text { 1995, 1998, } \\
\text { 2004-2008, } \\
\text { 2010-present }\end{array}$ & $\begin{array}{l}\text { Arts and Humanities: } \\
\text { Visual Arts and Performing } \\
\text { Arts } \\
\text { Social Sciences: Cultural } \\
\text { Studies; Communication }\end{array}$ & 26 & 2.4 & 0.659 & 2.020 & Q1 & 17 & 14 \\
\hline IOP Conference & & Environmental Science: & & & & & & & \\
\hline $\begin{array}{l}\text { Series: Earth } \\
\text { and } \\
\text { Environmental } \\
\text { Science }\end{array}$ & $\begin{array}{l}\text { from } 2010 \text { to } \\
\text { present }\end{array}$ & $\begin{array}{l}\text { General Environmental } \\
\text { Science; General Earth } \\
\text { and Planetary Sciences }\end{array}$ & 18 & 0.4 & 0.175 & 0.514 & - & 17 & 4 \\
\hline $\begin{array}{l}\text { European } \\
\text { Planning } \\
\text { Studies }\end{array}$ & $\begin{array}{l}\text { from } 1993 \text { to } \\
\text { present }\end{array}$ & $\begin{array}{l}\text { Social Sciences: } \\
\text { Geography, Planning and } \\
\text { Development }\end{array}$ & 75 & 4.0 & 0.953 & 1.345 & Q1 & 14 & 14 \\
\hline Regional & from 1967 to & $\begin{array}{l}\text { Social Sciences: General } \\
\text { Social Sciences } \\
\text { Environmental Science: }\end{array}$ & 111 & 5.8 & 1.543 & 2.021 & Q1 & 14 & 14 \\
\hline Studies & present & $\begin{array}{l}\text { General Environmental } \\
\text { Science }\end{array}$ & & & & & & & \\
\hline
\end{tabular}

Sources: developed by the authors using data from Scopus, Scimagojr and WoS. 
Eight of the ten most cited articles were published by high-ranking journals from both databases (Table 2). The most cited papers were published by the scientists Gregory K. B., Vidic R. D. and Dzombak D. A. in 2011 in the scientific journal «Elements». Notably, this paper (Gregory et al., 2011) was cited 522 times in Scopus and 478 times in WoS databases. In 2008, Ann Markusen (a famous expert of Council on Foreign Relations, USA) and her colleagues published the article «Defining the creative economy: Industry and occupational approaches» (Markusen et al., 2008). The study was cited 175 times in journals, indexed by Scopus and 146 times in WoS databases. In the study frame, the authors try to evaluate the creative economy size in the Boston metropolis. They demonstrated a combination of governance methods of cultural policy realization and the creative region's development (Table 3).

Table 2. The most cited papers on creative management or creativity in management presented in the Scopus database (1950-2020)

\begin{tabular}{|c|c|c|c|c|}
\hline \multirow[b]{2}{*}{ Authors and Title } & \multirow[b]{2}{*}{ Year } & \multirow[b]{2}{*}{ Source title } & \multicolumn{2}{|c|}{ Cited } \\
\hline & & & 今 & $\stackrel{\mathscr{O}}{3}$ \\
\hline $\begin{array}{l}\text { Gregory, K. B., Vidic, R. D., \& Dzombak, D. A. Water management } \\
\text { challenges associated with the production of shale gas by hydraulic } \\
\text { fracturing. }\end{array}$ & 2011 & Elements & 522 & 478 \\
\hline $\begin{array}{l}\text { Morris, M. G. The effects of structure and its dynamics on the ecology } \\
\text { and conservation of arthropods in british grasslands }\end{array}$ & 2000 & Biological Conservation & 291 & 275 \\
\hline $\begin{array}{l}\text { Gertler, M. S. Rules of the game: The place of institutions in regional } \\
\text { economic change. }\end{array}$ & 2010 & Regional Studies & 246 & \\
\hline $\begin{array}{l}\text { Storper, M., \& Manville, M. Behaviour, preferences and cities: Urban } \\
\text { theory and urban resurgence. }\end{array}$ & 2006 & Urban Studies & 217 & 187 \\
\hline Flew, T. The creative industries: Culture and policy. & 2012 & $\begin{array}{l}\text { The creative industries: } \\
\text { Culture and } \\
\text { policy (Book) }\end{array}$ & 178 & \\
\hline $\begin{array}{l}\text { Markusen, A., Wassall, G. H., DeNatale, D., \& Cohen, R. Defining the } \\
\text { creative economy: Industry and occupational approaches. }\end{array}$ & 2008 & $\begin{array}{l}\text { Economic Development } \\
\text { Quarterly }\end{array}$ & 175 & 146 \\
\hline $\begin{array}{l}\text { Banks, M., \& Hesmondhalgh, D. Looking for work in creative industries } \\
\text { policy. }\end{array}$ & 2009 & $\begin{array}{l}\text { International Journal of } \\
\text { Cultural Policy }\end{array}$ & 164 & 161 \\
\hline $\begin{array}{l}\text { Waitt, G., \& Gibson, C. Creative small cities: Rethinking the creative } \\
\text { economy in place }\end{array}$ & 2009 & Urban Studies & 148 & 126 \\
\hline Keane, M. Created in china: The great new leap forward. & 2007 & $\begin{array}{l}\text { Created in china: The } \\
\text { great new leap forward } \\
\text { (Book) }\end{array}$ & 142 & \\
\hline $\begin{array}{l}\text { Comunian, R. Rethinking the creative city: The role of complexity, } \\
\text { networks and interactions in the urban creative economy }\end{array}$ & 2011 & Urban Studies & 138 & 121 \\
\hline
\end{tabular}

Sources: developed by the authors using data from Scopus and WoS.

VOSviewer software allows identifying the clusters of paper co-citing on creative management or creativity in management, which confirm the leading role of the most cited publications and most productive authors (Figure 6).

Using Scopus and Wos databases tools, it is possible to define the authors with the biggest number of publications devoted to creative management or creativity in management. Among the most active authors in this sphere is scientist Lily Kong from Singapore Management University (Singapore City, Singapore). He published 8 papers on creative management or creativity in management in journals indexed by Scopus issues. Besides, the scientist's h-index is 30 in Scopus (Table 3). 


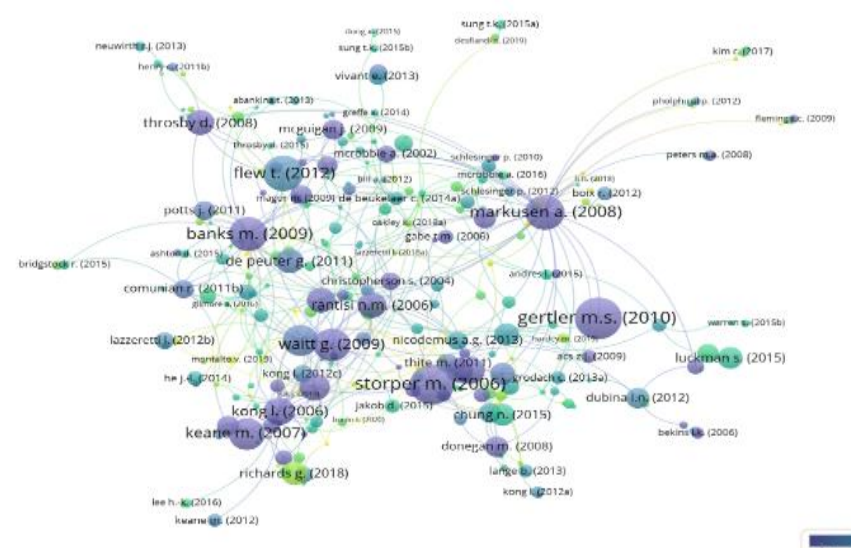

Figure 6. The overlay visualization of the co-citation of the papers on creative management or creativity in management

Sources: developed by the authors using VOSviewer software tool.

In turn, Roberta Comunian, a professor at King's College London (London, United Kingdom), is the most active author on creative management or creativity in management. She published 14 papers indexed by Scopus and 15 - by WoS (Table 3).

Table 3. Top 5 most productive authors investigating issues of creative management or creativity in management by Scopus database (1950-2020)

\begin{tabular}{|c|c|c|c|c|c|}
\hline \multirow{2}{*}{ Authors } & \multirow{2}{*}{ Affiliation } & \multirow{2}{*}{ Subject Areas } & \multirow{2}{*}{ 希 } & \multicolumn{2}{|c|}{$\begin{array}{c}\text { Number } \\
\text { of } \\
\text { docume } \\
\text { nts }\end{array}$} \\
\hline & & & & 号 & $\stackrel{20}{3}^{\circ 0}$ \\
\hline $\begin{array}{l}\text { Comunian, } \\
\text { Roberta }\end{array}$ & $\begin{array}{l}\text { King's College } \\
\text { London, London, } \\
\text { United Kingdom }\end{array}$ & $\begin{array}{l}\text { Social Sciences, Business, Management and } \\
\text { Accounting, Environmental Science } \\
\text {,Economics, Econometrics and Finance, Arts } \\
\text { and Humanities }\end{array}$ & 13 & 14 & 15 \\
\hline $\begin{array}{l}\text { Kačerauskas, } \\
\text { Tomas }\end{array}$ & $\begin{array}{l}\text { Vilniaus } \\
\text { Gedimino } \\
\text { Technikos } \\
\text { Universitetas, } \\
\text { Vilnius, Lithuania }\end{array}$ & $\begin{array}{l}\text { Social Sciences } \bullet \text { Arts and Humanities } \bullet \\
\text { Business, Management and Accounting } \\
\text { Economics, Econometrics and Finance } \bullet \\
\text { Environmental Science } \bullet \text { Energy } \bullet \text { Mathematic }\end{array}$ & 10 & 9 & 10 \\
\hline $\begin{array}{l}\text { Kong, Lily } \\
\text { L.L. }\end{array}$ & $\begin{array}{l}\text { Singapore } \\
\text { Management } \\
\text { University, } \\
\text { Singapore City, } \\
\text { Singapore }\end{array}$ & $\begin{array}{c}\text { Social Sciences } \bullet \text { Environmental Science } \\
\text { Arts and Humanities } \bullet \text { Earth and Planetary } \\
\text { Sciences } \bullet \text { Economics, Econometrics and } \\
\text { Finance } \bullet \text { Agricultural and Biological Sciences } \\
\cdot \text { Medicine } \bullet \text { Business, Management and } \\
\text { Accounting } \bullet \text { Nursing }\end{array}$ & 30 & 8 & - \\
\hline
\end{tabular}




\begin{tabular}{|c|c|c|c|c|c|}
\hline & & & & & \\
\hline $\begin{array}{l}\text { Lazzeretti, } \\
\text { Luciana }\end{array}$ & $\begin{array}{l}\text { Università degli } \\
\text { Studi di Firenze, } \\
\text { Florence, Italy }\end{array}$ & $\begin{array}{c}\text { Social Sciences } \bullet \text { Business, Management and } \\
\text { Accounting } \bullet \text { Economics, Econometrics and } \\
\text { Finance } \cdot \text { Environmental Science } \bullet \\
\text { Engineering } \bullet \text { Arts and Humanities } \\
\text { Veterinary }\end{array}$ & 17 & 8 & 4 \\
\hline $\begin{array}{l}\text { Schlesinger, } \\
\text { Philip }\end{array}$ & $\begin{array}{l}\text { University of } \\
\text { Glasgow, } \\
\text { Glasgow, United } \\
\text { Kingdom }\end{array}$ & $\begin{array}{c}\text { Social Sciences } \bullet \text { Arts and Humanities } \bullet \\
\text { Business, Management and Accounting } \bullet \\
\text { Mathematics } \bullet \text { Biochemistry, Genetics and } \\
\text { Molecular Biology } \bullet \text { Physics and Astronomy } \bullet \\
\text { Medicine } \bullet \text { Pharmacology, Toxicology and } \\
\text { Pharmaceutics } \bullet \text { Economics, Econometrics } \\
\text { and Finance }\end{array}$ & 19 & 8 & 11 \\
\hline
\end{tabular}

Sources: developed by the authors based on Scopus and WoS data.

Figure 7 demonstrates the paper co-citing clusters, which confirm the leading role of the most cited publications and most productive authors.

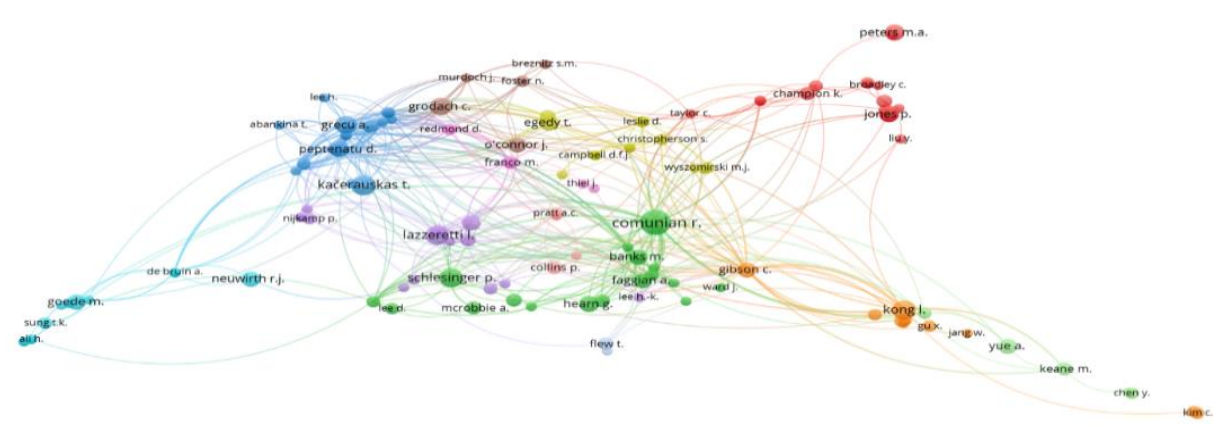

Figure 7. The network visualization of the co-citation of authors of the papers on the creative management or creativity in management

Sources: developed by the authors using VOSviewer software tool.

Figure 8 demonstrates the allocation of authors co-citing from 2012 to 2018.

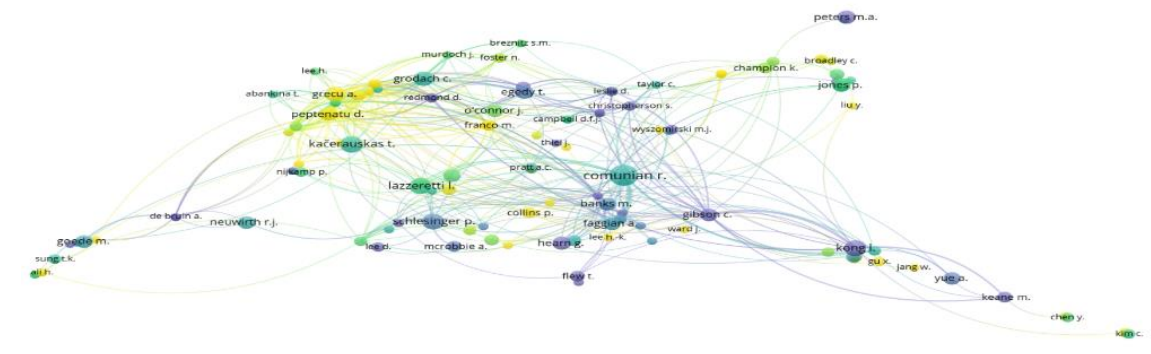

Figure 8. The overlay visualization of the co-citation of authors of the papers on the creative management or creativity in management

Sources: developed by the authors using VOSviewer software tool. 
Using VOSviewer software allowed defining 8 clusters of the papers thematic directions on creative management or creativity in management (Figure 9). Time allocation of keywords is demonstrated in Figure 10.

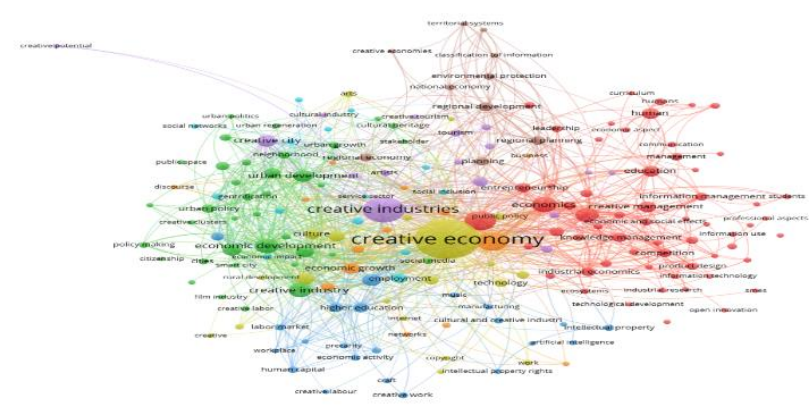

Figure 9. The network visualization of the keyword co-occurrences in the papers' on creative management or creativity in management

Sources: developed by the authors using VOSviewer software tool.

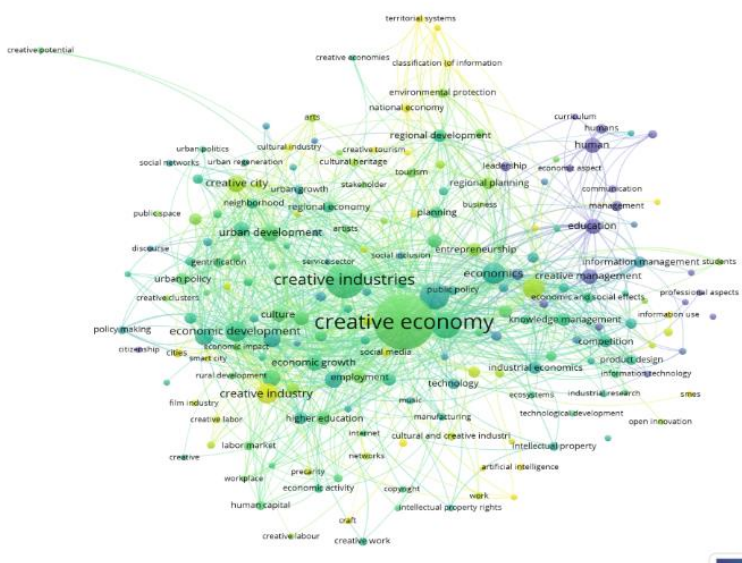

Figure 10. The overlay visualization of the keyword co-occurrences in the papers on creative management or creativity in management time allocation

Sources: developed by the authors using VOSviewer software tool.

The biggest cluster is (red) consists of 60 items such as big data, commerce, communication, competition, competitiveness, creative management, creative society, creativity, decision making, decision, ecology, economic and social effect, ecosystems, education, enterprise, entrepreneurship, government, human resource management, industrial research, information and communication, information society, information management, information system, information technology, knowledgebased system, knowledge management, motivation, marketing, open innovation, product decision, product development, project management, research and development, SMEs, surveys, strategic planning, sustainable development, technological development etc. (Figure 11). Therefore, it affirms the 
ascertained fact of a separate research area on creative management or creativity in management issues - issues of influence of digitalization and education on developing creative economy and management and governance processes in these features.

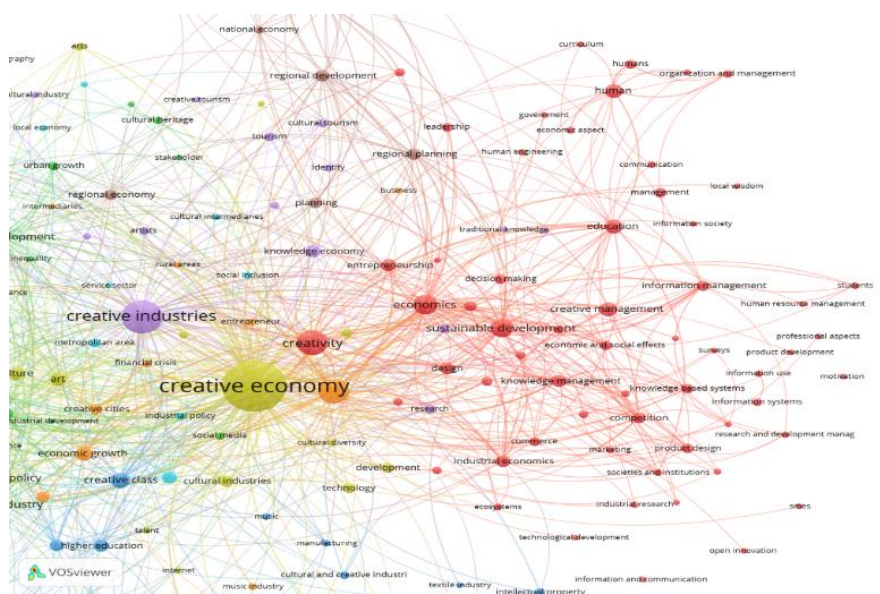

Figure 11. The network visualization of the keyword co-occurrences by red cluster Sources: developed by the authors using the Scopus and WoS database and VOSviewer tool.

The second-largest green cluster (37 items) merged the keywords from the field of urban economy and development of creative industries as follows: cities, citizenship, creative clusters, creative industry, cultural economy, creative labour, development strategy, cultural economy, cultural heritage, culture influence, culture planning, gentrification, globalization, governance approach, economic development, industrial development, film industry, institutional framework, policymaking, policy approach, public space, smart city, social media, stakeholder, tourism development, urban development, urban growth, urban planning, urban policy (politics), urbanization, urban renewal, urban regeneration etc. (Figure 12).

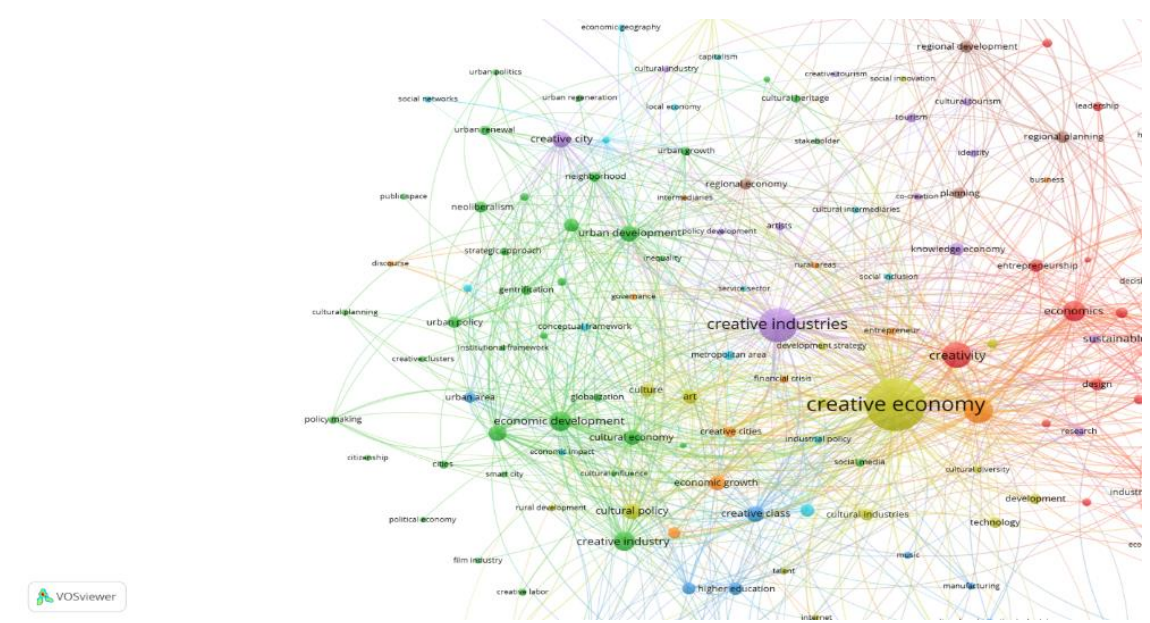

Figure 12. The network visualization of the keyword co-occurrences by green and yellow clusters Sources: developed by the authors using VOSviewer software tool. 
The third blue (22 items) and fourth yellow (21 items) clusters are almost similar. Figure 13 demonstrates that the blue cluster focused on artificial intelligence, craft, creative class, creative labour, creative work, cultural and creative industry, economic activity, higher education, human capital, intellectual property, intellectual property right, knowledge, labour market, new economy, precarity, textile industry, urban area, workplace etc. In turn, it verified the ascertained in the scientific background fact of the existence of a particular area of research on the creative management or creativity in management issues - protection of intellectual property right. The yellow cluster connected the paper including the keywords such as art, copyright, creative, creative economy, cultural diversity, cultural industries, culture, cultural policy, development, development strategy, internet, policy, rural development, social innovation, talent, technology, work etc. (Figure 12).

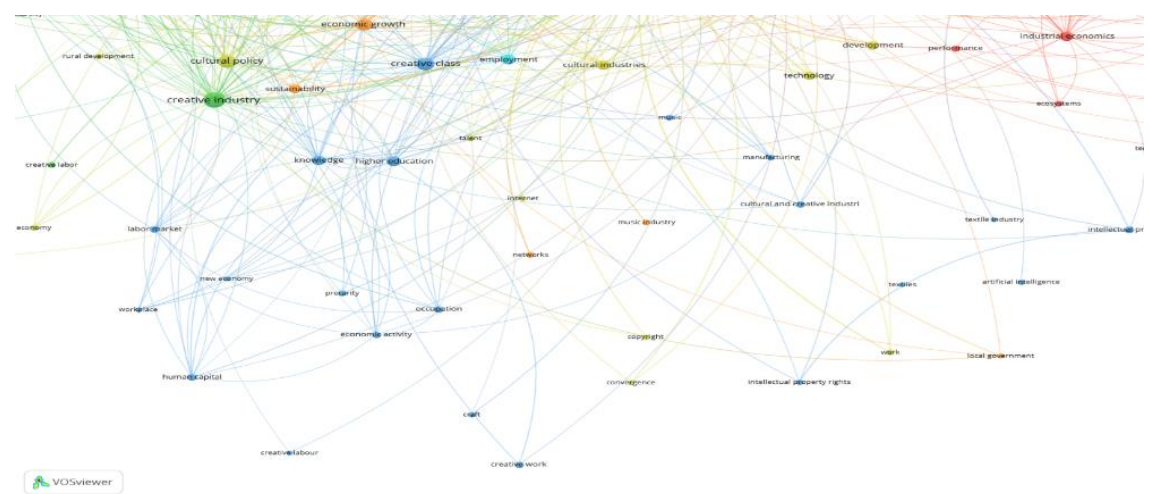

Figure 13. The network visualization of the keyword co-occurrences by blue cluster Sources: developed by the authors using VOSviewer software tool.

The next three clusters are also very similar in size. The violet cluster consists of 16 items, turquoise - 14 keywords, orange - 14 keywords. In turn, the violet cluster contained such keyword as artists, cocreation, creative city, creative industry, creative potential, creative tourism, economic growth, knowledge economy, research, tourism, traditional economy etc. Turquoise cluster based on the keywords such as agglomeration, capitalism, conceptual framework, cultural intermediaries, economic impact, employment, industrial policy, local economy, metropolitan area, service sector, social inclusion, social network etc. (Figure 14).

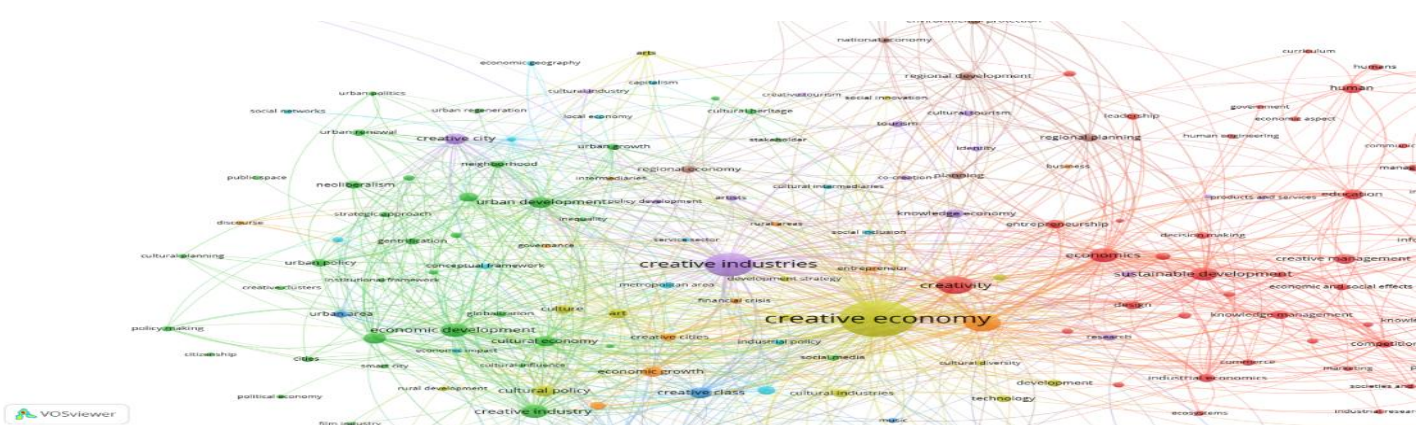

Figure 14. The network visualization of the keyword co-occurrences by violet and turquoise clusters

Sources: developed by the authors using VOSviewer software tool. 
Orange cluster merged keywords as follows: business, creative cities, discourse, economic growth, entrepreneur, financial crises, governance, innovation, intermediaries, rural areas, sustainability etc. (Figure 15). The brown cluster covers keywords such as creative economies, environmental protection, government decision, planning, regional development, regional planning, territorial systems etc.

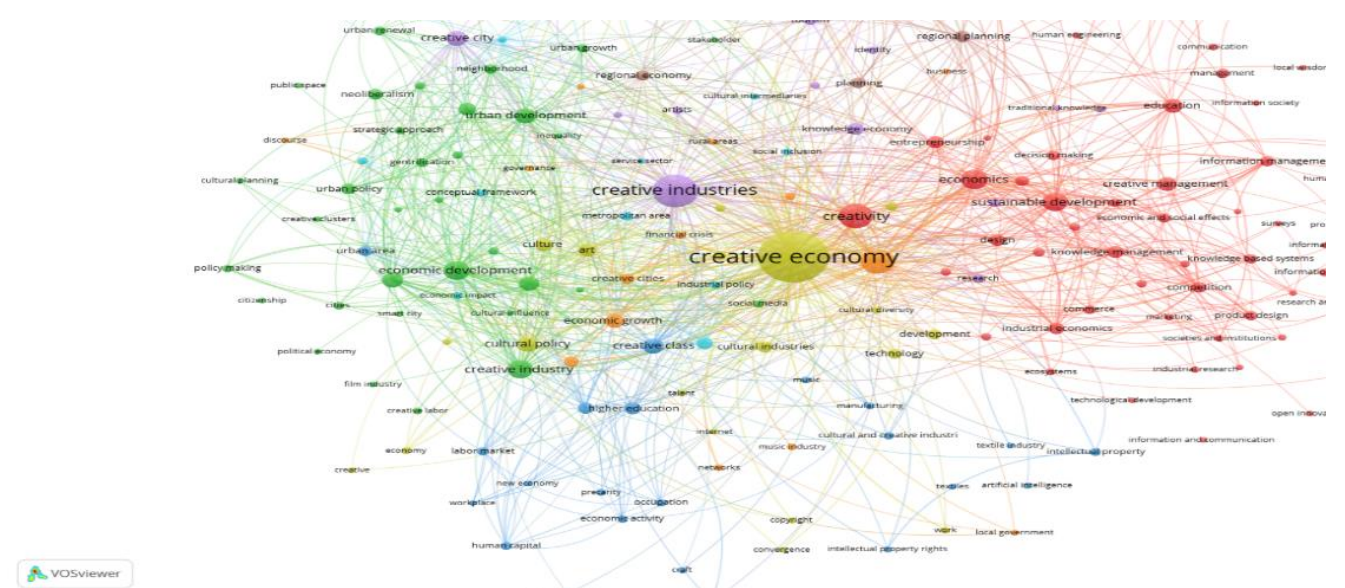

Figure 15. The network visualization of the keyword co-occurrences by orange cluster Sources: developed by the authors using VOSviewer software tool.

It stands to note that all clusters are very close to each other. Besides, they are connected through the basic terms «creative economy», "creative industry», «creativity», etc. Notably, given the keywords chronology, the earliest keywords are education, creative management, curriculum, leadership, human. The most recent connections are correlated to the keywords such as cities, territorial system, creative industry, film industry etc.

Conclusions. The analysis findings proved that creative management or creativity in management issues is one of the mainstreams in the papers devoted to modern management, which formed different scientific directions. The investigation findings allow concluding that the topic of «creative management» or «creativity in management» wasn't popular among scientists until 2004 in the WoS database and 2006 in Scopus. The number of papers had been growing up to 2018 throughout the analyzed period at an average growth rate of almost $50 \%$ in the WoS database and $39 \%$ in the Scopus database. Using VOSviewer software allowed defining 8 clusters of keywords co-occurrences in the papers devoted to creative management or creativity in management. Besides, all of them have a close connection. The biggest cluster consists of 60 items such as big data, commerce, communication, competition, competitiveness, creative management, creative society, information and communication, information society, information management, information system, information technology, knowledge-based system, knowledge management, SMEs, surveys, strategic planning, sustainable development, technological development etc. The second biggest cluster merged the sphere of urban economy and the development of the creative industry. The findings proved that intellectual property rights protection is an important part of creative management or creativity in management issues. Besides, the obtained results showed that it gained popularity in the last decade in analyses. 


\section{References}

Banks, M., \& Hesmondhalgh, D. (2009). Looking for work in creative industries policy. International journal of cultural policy, 15(4), 415-430. [Google Scholar] [CrossRef]

Banks, M., Calvey, D., Owen, J., \& Russell, D. (2002). Where the art is: Defining and managing creativity in new media SMEs. Creativity and innovation management, 11(4), 255-264. [Google Scholar] [CrossRef]

Bennett, A. C. (1979). Creative management engineers foster communication, change. Hospitals, 53(2), 101-103. [Google Scholarl

Beswick, D. G. (1988). Prospects for the 1990s: A New Phase of Development in Australian Higher Education. Higher Education Quarterly, 42(2), 162-178. [Google Scholar] [CrossRef]

Bliss, D. (1970). Creative management-dealing with change by design. Public welfare, 28(3), 265-270.

Boiarko, I. M. (2016). Praxeological and situational approaches in the formation of strategic accounting. Financial and credit activities: problems of theory and practice, 2(21), 80-90. [CrossRef]

Bordinat, G. (1961). Creative Design for Creative Management (No. 610130). SAE Technical Paper. [CrossRef]

Burstiner, I. (1977). Creative management training for department store middle managers: An evaluation. The Journal of Creative Behavior, 11(2), 105-108. [Google Scholar] [CrossRef]

Donegan, M., \& Lowe, N. (2008). Inequality in the creative city: is there still a place for «old-fashioned» institutions?. Economic Development Quarterly, 22(1), 46-62. [Google Scholar] [CrossRef]

Edwards, L., Klein, B., Lee, D., Moss, G., \& Philip, F. (2013). Framing the consumer: Copyright regulation and the public. Convergence, 19(1), 9-24. [Google Scholar] [CrossRef]

Esen, U. B., \& Özlem, A. T. A. Y. (2020). Turkiye'nin yaratıcı Sehirleri. Bilig, (92), 29-54. [Google Scholar] [CrossRef]

Farida, N., Nugraha, H. S., Naryoso, A., \& Ardyan, E. (2021). SMEs Development Strategy Model Based on Creative Economy With Quadruple Helix Approach. International Journal of Social Ecology and Sustainable Development (IJSESD), 12(1), 33-46. [Google Scholar]

Flew, T. (2012). The Creative Industries, Culture and Policy. [Google Scholar]

Florida, R. (2011). Globalization: Part I. The wiley-blackwell companion to human geography (pp. 283-297) [Google Scholar] [CrossRef]

Gertler, M. S. (2010). Rules of the game: The place of institutions in regional economic change. Regional Studies, 44(1), 1-15. [Google Scholar] [CrossRef]

Gregory, K. B., Vidic, R. D., \& Dzombak, D. A. (2011). Water management challenges associated with the production of shale gas by hydraulic fracturing. Elements, 7(3), 181-186. [Google Scholar] [CrossRef]

Keane, M. (2007). Created in China: The great new leap forward. Routledge. [Google Scholar]

Kuzior, A., Kwilinski, A., \& Tkachenko, V. (2019). Sustainable development of organizations based on the combinatorial model of artificial intelligence. Entrepreneurship and Sustainability, 7(2), 1353-1376. [CrossRef]

Kuznetsova A., Kalynets K., Kozmuk N. (2018). Innovative management in global financial csr governance. Marketing and management of innovations, 2. P. 262-269. [CrossRef]

Kuznyetsova A. Ya., Zherebylo I. V., Klipkova O. I., Kozmuk N. I. (2019). Creation of the value of national enterprises with the help of the innovation centers in the cluster formations. Financial and credit activities: problems of theory and practice, 2(29), 391 . 402. [Google Scholar] [CrossRef]

Markusen, A., Wassall, G. H., DeNatale, D., \& Cohen, R. (2008). Defining the creative economy: Industry and occupational approaches. Economic development quarterly, 22(1), 24-45. [Google Scholar] [CrossRef]

Morris, M. G. (2000). The effects of structure and its dynamics on the ecology and conservation of arthropods in British grasslands. Biological conservation, 95(2), 129-142. [Google Scholar] [CrossRef]

Neuwirth, R. J. (2013). The Future of the 'Culture and Trade Debate': A Legal Outlook. Journal of World Trade, 47(2). [Google Scholar]

Nurani, N., Maya, Y., \& Kaniawati, K. (2020). Protection of the IPR (Intellectual Property Rights) for the Culinary Industry through Law No. 30 Of 2000 Concerning Trade Secrets Related to Franchise Agreements Supporting Indonesian Creative Economy Growth. International Journal of Psychosocial Rehabilitation, 24(2). [Google Scholar]

Pointer, D. D. (1976). Catholic hospitals' dual nature complicates labor relations strategy. Hospital progress, 57(2), 5861. [Google Scholar]

Rausser, G., Strielkowski, W., \& Štreimikienè, D. (2018). Smart meters and household electricity consumption: A case study in Ireland. Energy \& Environment, 29(1), 131-146. [CrossRef]

Rodríguez Gómez, A. E., \& Rojas Rosario, H. A. (2018). Aplicaciones móviles: protección jurídica desde el ámbito de la propiedad intelectual en Colombia (Mobile Applications (APPS): Legal Protection From the Field of Intellectual Property). La Propiedad Inmaterial, (26). [Google Scholar]

Rosiek-Kryszewska, A., \& Rosiek, A. (2018). The Impact of Management and Leadership Roles in Building Competitive Healthcare Units. In Healthcare Administration for Patient Safety and Engagement (pp. 13-30). IGI Global. [Google Scholar] [CrossRef] 


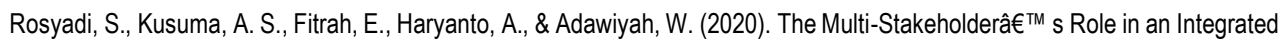
Mentoring Model for SMEs in the Creative Economy Sector. SAGE Open, 10(4). [Google Scholar] [CrossRef]

Sengun, H. (2016). Innovation in Health Care Delivery. Haseki Tip Bulteni, 54, 194-198. [CrossRef]

Storper, M., \& Manville, M. (2006). Behaviour, preferences and cities: Urban theory and urban resurgence. Urban studies, 43(8), 1247-1274. [Google Scholar] [CrossRef]

Teresa, B. F., \& Zitcer, A. (2020). The specter of the «art-less city»: Locating artists in Philadelphia's creative economy. Journal of Urban Affairs, 1-20. [Google Scholar] [CrossRef]

Tkachenko, V., Kwilinski, A., Tkachenko, I., \& Puzyrova, P. (2019). Theoretical and Methodical Approaches to the Definition of Marketing Risks Management Concept at Industrial Enterprises. Marketing and Management of Innovations, 2, 228-238. [CrossRef]

Vasylieva, T., Bilan, Y., Starchenko, L., \& Woźniak, A. (2020). Green Intellectual capital for sustainable business model: bibliometric analysis. In Proceedings of the 34th International Business Information Management Association (IBIMA) conference. Retrieved from [Link]

Waitt, G., \& Gibson, C. (2009). Creative small cities: Rethinking the creative economy in place. Urban studies, 46(5-6), 12231246. [Google Scholar] [CrossRef]

WEF. (2020). The Future of Jobs Report. Retrieved from [Link]

Yakymchuk, B. A., Chystiak, O. V., Padalka, R. G., Moskalyk, H. F., \& Denha, N. M. (2020). Fostering Cognitive and Creative Thinking Styles Using Educational Tools Aimed at the «Creative Economy» Model in the Process of Vocational Education and Training. Psychology and education, 57(1), 01-07. [Google Scholar]

Yue, Z., \& Zhao, K. (2020). Understanding the Effectiveness of Higher Education System: Evidences from Market Outcomes of Early University Graduates in Seven European Countries. Sustainability, 12(18), 7761. [Google Scholar] [CrossRef]

Zelina, M. (1992). Creativization of Personality-the Need to Study it. Studia psychologica, 34(4), 367. [Google Scholar] []

Zhou, F., He, Y., Ma, P., \& Mahto, R. V. (2020). Knowledge management practice of medical cloud logistics industry: transportation resource semantic discovery based on ontology modelling. Journal of Intellectual Capital. [Google Scholar] [CrossRef]

Ірина Саух, д.е.н., професор, Житомирський державний університет імені Івана Франка, Україна

Ольга Вікарчук, Ph.D., доцент, Житомирський державний університет імені Івана Франка, Україна

Креативність в менеджменті та креативний менеджмент: мета-аналіз

Роль менеджменту, як одного із головних факторів у забезпеченні ефективності та конкурентоспроможності економіки країн, що розвиваються, набула значної популярності протягом минулого століття. При цьому систематизація наукових напрацювань засвідчила, що дослідження креативного менеджменту або креативності в менеджменті $є$ одними з основних напрямків сучасних наукових досліджень. Виходячи із вищезазначеного, головною метою дослідження $є$ аналіз основних напрямків наукових досліджень, присвячених питанням креативного менеджменту та креативності у менеджменті. У робот авторами розкрито сутність концепції «креативного менеджменту» як однієї зі складових системи управління підприємством. Вихідними даними для дослідження стали наукові публікації, представлені у наукових базах даних Scopus тa Web of Science. Вибірка дослідження сформована без часових обмежень. Результати аналізу динаміки публікаційної активності свідчать про те, що популярність досліджуваної тематики почала зростати з 2004 року у базі даних Scopus та з 2006 року у базі даних Web of Science. При цьому середній рівень зростання наукових публікацій з 2004 по 2018 роки становив 50\% у базі даних Scopus та $39 \%$ у базі даних Web of Science. Практичну реалізацію даного дослідження було здійснено 3 використання інструментарію програмного забезпечення VOSviewer. За результатами візуалізовано 8 кластерів тематичних напрямів досліджень, які мають тісні зв'язки. Найбільший кластер сформовано із 60 термінів, серед яких: великі дані, торгівля, комунікація, конкуренція, конкурентоспроможність, креативний менеджмент, креативне суспільство, інформація та комунікації, інформаційне суспільство, управління інформацією, інформаційна система, інформаційні технології, система бази знань, управління знаннями, МСП, опитування, стратегічне планування, сталий розвиток, технологічний розвиток тощо. При цьому другий кластер вказує на напрямки досліджень у сфері міської економіки та розвитку креативної економіки. Таким чином, результати дослідження дають підстави стверджувати, що захист прав інтелектуальної власності $є$ важливою складовою креативного менеджменту або креативності у менеджменті. У статті автори приходять до висновку, щодо постійно зростальної тенденції у розширенні частки організаційно-управлінських інновацій в управлінні організацією.

Ключові слова: креативний менеджмент, креативність в менеджменті, креативна економіка. 